nothing but fuel from a few fully safeguarded plants. Victoria Johnson and Carlos Astiz are driven back to suggesting Paraguay or Uruguay as the only possible hosts for a Latin American store. Richard Broinowski is hardly more optimistic about Asia and the Middle East, and Robert Gallucci even less encouraging, if that is possible, about Western Europe. At the end, therefore, the editors, concluding sadly that there is little chance of rational economic arguments overriding "the centrifugal forces of international politics", leave one asking whether the dinner was worth the detour.

It may be because their surveys of regional politics so depressed them that the editors and authors found no reason even to consider some of the most obtrusive problems in working towards international or multinational fuel cycle arrangements. There is no discussion here of the criteria which should govern the release of spent fuel from international custody. There is almost nothing about institutional form or organization: how rights, responsibilities, costs or authority might be pooled, distributed or devolved. These are glaring omissions, which inevitably detract from the book's value. They might nevertheless be justified if the political prospects were as impenetrably gloomy as here indicated. The hard fact, however, is that the political analyses in the volume often verge on the simplistic, and are forced, moreover, towards pessimism by questionable underlying assumptions: that international arrangements for spent fuel storage must, for example, be addressed in isolation from other fuel cycle functions, or that membership of any multinational fuel cycle institution must be drawn from a single geographical region. Above all, those responsible for the study have steered so far away from the Scylla of believing that political obstacles will vanish in the face of an intellectually coherent scenario that they have fallen victim to the Charybdis of equating the politically. difficult with the palpably impossible.

The authors are to be praised for venturing into turbulent waters which it may be politically essential for governments to explore thoroughly during the next few years, and for setting up some preliminary aids to navigation. At the end of the day, however, their courage seems to have failed, because they have judged the icebergs of politics to be immutable. It is not necessary, and it may not be wise, to assume that national policies must be as unalterable, or diplomacy always as impotent, as their conclusions would suggest.

Ian Smart is an independent adviser on international energy affairs, and was Chairman of the International Consultative Group on Nuclear Energy (1977-80).

\section{Learning from the Arctic peoples}

\section{John Ebling}

The Human Biology of Circumpolar Populations. International Biological Programme 21. Edited by F.A. Milan. Pp.367. (Cambridge University Press: Cambridge, 1980.) £35, \$75.

ThE Arctic regions were the last major environment to be conquered by Homo sapiens. The radiation of human beings into colder climes northwards and southwards from the tropics probably started about half a million years ago and extended into western and central Europe under conditions of great cold during the Pleistocene. At the end of the Old Stone Age, the use of clothing enabled the human hunters to follow the retreating ice of the Third Würm Glaciation into the Eurasiatic land mass and finally to move into the New World. What adaptations were involved? In general, the physiological differences between modern circumpolar peoples and those more favoured climatically are not striking. They may, perhaps, show an earlier onset of cold vasodilation and have uniformly warmer fingers, but their eyes differ little, even though they are exposed to continuous low temperatures, blowing snow in winter and high ultraviolet radiation in spring. In the far Arctic, people survive mainly on protein, without any obvious source of essential vitamins, and generate necessary glucose from amino acids. The polyunsaturated fats from seal and whale oils keep plasma cholesterol and heart disease at enviably low levels.

The Human Biology of Circumpolar
Populations is an admirably edited source book with contributions from Canada, the USA, Denmark, Norway, Finland, France and the USSR. The chapters deal in turn with the demography, genetics, craniofacial features, ophthalmology, anthropometry, nutrition, physiology and behaviour of the 16 indigenous Arctic peoples, ranging from the Lapps of Scandinavia to the Eskimos of Greenland and including the lesser known Siberian groups and the Ainu.

The publication of such a book, and the special studies of the International Biological Programme which went into its making, are timely. The circumpolar peoples are changing. Alcoholism, leading to accidents, violence and other social disorders, is on the increase. There is much that our society needs to learn from them before they are destroyed by contact with us.

John Ebling is Professor of Zoology in the University of Sheffield, UK.

\section{Ecological view of marine animal diseases}

\section{R.J. Roberts}

Diseases of Marine Animals. Vol.1. Edited by $\mathrm{O}$. Kinne. Pp. 466. (Wiley: Chichester, UK, and New York, 1980.) £25, \$73.15.

BECAUSE of the span of our knowledge, and the complexity of the subject, pathology books are nowadays generally multi-author volumes which deal with a single species (usually human beings) or even a single organ system. Comparative pathology texts are few and generally relate to specifically defined groups of economic significance such as domesticated animals or teleost fish. Only a brave, or naive, person would attempt to write a textbook covering the diseases of virtually the entire animal kingdom in so far as it inhabits the marine environment. Surprisingly this brave man is not Otto Kinne, whose name appears as editor on the cover of this first volume in a series of four, but one G.H.
Lauckner who has apparently been responsible for the entire content of all four volumes apart from the two very general introductory chapters. He appears to have received less than adequate credit for this mammoth task.

Dr Kinne is a distinguished marine ecologist and in the foreword to this first volume he gives his view that disease is primarily an ecological phenomenon. This is a very different attitude to that of the majority of comparative pathologists and, I suspect, of commercial aquaculturists and fishery biologists as well. It is true, however, that marine ecologists have too often focused exclusively on holistic ecosystem properties and food-web interrelations in ignorance of the impact of diseases on populations. It is a stated aim of this series to synthesize all of the information available to allow the ecological significance of diseases in the marine environment to be appreciated.

This first volume covers the lowe invertebrates, ranging from the Protozo: to the Gastropoda. These are the group: covered by the smallest amount 0 published literature in comparativi pathology, and thus for many of them the 